\title{
REVIEW OF WASTEWATER REUSE IN THE MEDITERRANEAN COUNTRIES, FOCUSING ON REGULATIONS AND POLICIES FOR MUNICIPAL AND INDUSTRIAL APPLICATIONS
}

\author{
M. KELLIS ${ }^{1}$ \\ I.K. KALAVROUZIOTIS ${ }^{1 *}$ \\ P. GIKAS ${ }^{2}$
}

\author{
${ }^{1}$ Department of Environmental and Natural Resources Management \\ University of Western Greece, G. Seferi 1 \\ 30100, Agrinion, Greece \\ ${ }^{2}$ Department of Environmental Engineering \\ Technical University of Crete \\ Chania, 73100, Greece
}

Received: 06/07/12

Accepted: 04/10/12 *to whom all correspondence should be addressed: e-mail: ikalavru@cc.uoi.gr

\begin{abstract}
The present paper reviews the wastewater reuse regulations, practices and applications of countries around the Mediterranean Region, particularly focusing on reuse practices for municipal and industrial uses. Water scarcity and water need is established in Mediterranean countries using international indexes for a cross-border comparison of water availability specifically for fresh water supply for municipal and industrial applications. Wastewater reuse criteria based on necessary, application specific, treatment output quality are presented. Data for each individual country is reviewed, and the regulations governing each country around reuse and applications are summarized, focusing, when appropriate, on the production and use of reclaimed wastewater for municipal and industrial applications. Also a critical overview of the guidelines and regulations governing these countries is presented. After considering multiple parameters associated with adoption of municipal and industrial wastewater reuse, such as water supply and scarcity, country and regional parameters, as well as possible applications, we note that adoption is accelerated in countries that have stronger economies and higher water needs. This development is fueled by favorable guidelines and regulations; conversely it is hindered by prohibitive guidelines and regulations. Wastewater reuse for municipal and industrial applications so far remains a whimsical game of culture, perception, religion, available technology and politics. An increasing trend in wastewater treatment plant construction and planning is seen in almost all the countries of the Mediterranean region. In addition, reuse water standards are in the process of being developed in a way that will clearly take into account the local conditions while reasonably safeguarding the public health. Wastewater reuse for municipal and industrial applications in Mediterranean countries remains at the beginning stages of adoption and the potential for improvement is open.
\end{abstract}

KEYWORDS: wastewater reuse, urban wastewater, reuse, municipal wastewater reuse, Mediterranean countries, guidelines, regulations.

\section{INTRODUCTION}

The Mediterranean offers a coastline to 21 countries yet the countries in this area are divided into 3 continents, and many more cultural subgroups. This paper is interested in reviewing wastewater reuse needs, practices and guidelines for Mediterranean countries, particularly focusing on wastewater reuse applications for municipal and industrial reuse when appropriate.

In the first section of this paper it is considered whether water need is indeed the main driver of wastewater reuse adoption. Water scarcity and water need is established in Mediterranean countries 
using international indexes for a cross-border comparison of water availability and specifically fresh water supply for municipal and industrial applications.

In the second section of this paper the wastewater treatment phases are outlined, in relation with the quality of treated wastewater, and its applicability for reuse, as wastewater treatment standards and practices vary significantly among the Mediterranean countries. Each country adopted guidelines that can be compared to those of WHO or USEPA. In this paper the national guidelines are primarily compared against the USEPA ones, as they are more stringent.

In the third section of this paper a detailed review of each Mediterranean country is given focusing on fresh water availability, general country characteristics, policies and regulations in place, wastewater treatment practices, and wastewater recycling and reuse applications, specifying when appropriate applications for municipal and industrial reuse. Emphasis is given on whether there is a direct link between the guidelines, laws and regulations of Mediterranean countries and the adoption of wastewater reuse practices for municipal and industrial applications.

From the 21 Mediterranean countries, 16 are reviewed in detail. Less attention is given to Monaco because of its small size and lack of independent water resources. Also the countries of the former Yugoslav Republic (Slovenia, Croatia, Bosnia and Herzegovina, Montenegro) and Albania are not studied in detail because of their general lack of infrastructure and consequently general lack of wastewater reuse practices and legislation.

In the fourth and last section of this paper a comparative review of guidelines and regulations governing Mediterranean countries is given, in order to determine whether a pattern of accelerated wastewater treatment, recycling and reuse can be established through the adoption of guidelines and regulations.

\section{WATER SUPPLY AND WATER SCARCITY}

The countries around the Mediterranean have significant levels of water scarcity, have increased water demand due to population influx, and are experiencing seasonal demand due to tourism (Iglesias et al., 2007). The above mentioned problems will only exacerbate in the forthcoming decades due to population increase and water consumption per capita increase (United Nations, 2006). Even though the total annually available volume of water per country in some instances might appear sufficient, geographical constraints and seasonal variations make for an insufficient water supply in most coastal areas (EUWI, 2008).

A number of indicators have been used to show the water availability profile for each country, thus quantifying the available supply of water. The level of supply of water and water availability is one of the main drivers of large scale wastewater reuse. In this paper the Total Actual Renewable Water per capita (TARWR) is used. The later indicator is tracked by the Food and Agricultural Organization of the United Nations (FAO) and thus can be deemed impartial for the purposes of this paper (FAO, 2009). It is noted that not all data was available for each country and that is due to country reporting practices, political situations, age of the country, as well as state of development of each country, reasons that are outside the scope of this paper to evaluate. The main indicator used is TARWR because it is an indicator that is internationally tracked as part of the Millenium Development Goals Indices (MDGI) of the United Nations.

In this paper, the total water withdrawal actual (TARWR actual) per capita which corresponds to the total annual amount of water withdrawn per capita is used. Whereas TARWR shows the total number of available resources per country, TARWR actual is a more pertinent indicator since it shows the actual water availability. This allows the calculation of the percentage of total actual renewable freshwater resources withdrawn (TARWR actual). The data is tabulated in Table 1 below. The countries of interest are shown in column 1, broken down by continent, Europe, Asia, and Africa. The total population in each country is shown in the second column, to give an indication of the size of each country. The third column show the TARWR data as reported by the FAO. The following columns allow to have a more complete picture of the TARWR usage since they include data for TARWR usage for freshwater usage and for agricultural usage. Since data is reported at different dates for each country the last column gives the date the data was reported. Also it is noted that some data is missing and this is due to the countries' reporting practices. 
Table 1. Water resources by country and by inhabitant, the TARWR indicator

\begin{tabular}{|c|c|c|c|c|c|}
\hline & $\begin{array}{c}\text { Total } \\
\text { population } \\
(1000 \\
\text { inhab) }\end{array}$ & $\begin{array}{l}\text { Total actual } \\
\text { renewable } \\
\text { water } \\
\text { resources } \\
\text { (TARWR) per } \\
\text { capita (m } \\
\text { inhab }^{-1} \mathrm{yr}^{-1} \text { ) }\end{array}$ & $\begin{array}{c}\begin{array}{c}\text { Percentage } \\
\text { of }\end{array} \\
\text { freshwater } \\
\text { TARWR } \\
\text { withdrawn } \\
\text { (\%) }\end{array}$ & 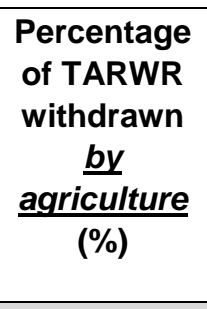 & $\begin{array}{c}\text { Year of Data } \\
\text { Supplied } \\
\text { (year) }\end{array}$ \\
\hline \multicolumn{6}{|l|}{ In Europe: } \\
\hline Spain & 45,638 & $2,443.00$ & 29.02 & 17.61 & 2008,2009 \\
\hline France & 62,445 & $3,379.00$ & 31.61 & 14.98 & 2007,2009 \\
\hline Monaco & 35 & & & & 2009 \\
\hline Malta & 415 & 121.70 & & 37.62 & 2009 \\
\hline Italy & 60,249 & $3,175.00$ & & & 2009 \\
\hline Slovenia & 2,024 & $15,746.00$ & 2.96 & 0.63 & 2009 \\
\hline Croatia & 4,411 & $23,917.00$ & 59.00 & 1.01 & 2009 \\
\hline Bosnia-Herz. & 3,768 & $9,952.00$ & 0.90 & & 2009 \\
\hline Montenegro & 624 & & & & 2009 \\
\hline Albania & 3,193 & $13,060.00$ & & & 2009 \\
\hline Greece & 11,327 & $6,596.00$ & 12.74 & 11.39 & 2007,2009 \\
\hline Cyprus & 1,090 & 715.60 & 19.29 & 20.38 & 2009 \\
\hline \multicolumn{6}{|l|}{ In Asia: } \\
\hline Turkey & 71,846 & $2,973.00$ & 18.77 & 13.86 & $2003,2007,2009$ \\
\hline Syria & 20,054 & 837.70 & 99.76 & 87.32 & $2005,2007,2009$ \\
\hline Lebanon & 4,197 & $1,073.00$ & 28.05 & 17.32 & 2007,2009 \\
\hline Palestine & 3,931 & 212.90 & 49.94 & 22.58 & $2005,2007,2009$ \\
\hline Israel & 7,261 & 245.10 & 101.90 & 63.43 & $2004,2007,2009$ \\
\hline \multicolumn{6}{|l|}{ In Africa: } \\
\hline Egypt & 79,716 & 718.80 & & & 2009 \\
\hline Libya & 6,263 & 95.80 & & & 2009 \\
\hline Tunisia & 10,365 & 443.30 & & & 2009 \\
\hline Algeria & 34,950 & 333.90 & & & 2009 \\
\hline Morocco & 31,635 & 916.70 & & & 2009 \\
\hline
\end{tabular}

Source: FAO (2009)

All data presented here is derived from United Nations' sources and is deemed accurate as such.

In Table 1 other indicators are also tabulated that show a more complete picture of the water supply, establishing though the water need for each country. The percentage of total actual renewable freshwater resources withdrawn is the total freshwater withdrawn in a given year, expressed in percentage of the actual total renewable water resources (TRWR_actual). This parameter is an indication of the pressure on the renewable water resources. It is calculated as follows [Freshwater withdrawal as \% of total renewable water resources (actual)] $=100$ * [Total freshwater withdrawal (surface water + groundwater)] / [Water resources: total renewable (actual)] (definition by $\mathrm{FAO}$ ).

WHO estimates that for a country to sustain its own agricultural production, the available water supply must be at least $750 \mathrm{~m}^{3}$ per capita per year. (WHO, 2006) Seven countries around the Mediterranean have less than $750 \mathrm{~m}^{3}$ per capita per year. Those countries are: Malta, Palestine, Isreal, Egypt, Libya, Tunisia, and Algeria. It is interesting to note that another five countries are "water stressed" with less than $1000 \mathrm{~m}^{3}$ per capita per year: Syria, Cyprus, Lebanon, Egypt and Morocco. Almost two thirds of the Mediterranean countries do not have long term sustainable water 
resources and this makes the need for finding alternatives sources of water pressing. It would be expected to see that those countries are the ones that have put the most effort into establishing regulations, into developing wastewater recycling and desalination plants, and into actively reusing recycled wastewater for applications other than just agricultural irrigation. It is apparent though that countries with a TARWR below $3.500 \mathrm{~m}^{3}$ inhab $\mathrm{yr}^{-1}$ to have a more highly developed wastewater reuse practice, expanding in particular on wastewater reuse for industrial and municipal applications, as these countries have a higher potential to explore alternative water supply options, such as water reclamation from wastewater.

Table 2. The MDGI Indicator for the Mediterranean Countries

\begin{tabular}{|c|c|c|c|}
\hline & $\begin{array}{l}\text { MDGI - Proportion of renewable } \\
\text { water resources withdrawn: } \\
\text { MDG Water Indicator (1990 or } \\
\text { 1995) (\%) }\end{array}$ & $\begin{array}{l}\text { MDGI - Proportion of } \\
\text { renewable water } \\
\text { resources withdrawn: } \\
\text { MDG Water Indicator } \\
(2001) \\
(\%)\end{array}$ & $\begin{array}{l}\text { MDGWI - Proportion of } \\
\text { renewable water } \\
\text { resources withdrawn: } \\
\text { MDG Water Indicator } \\
(2005 \text { or } 2010) \\
(\%) \\
\end{array}$ \\
\hline \multicolumn{4}{|c|}{ In Europe: } \\
\hline Spain & & 32 & 29 \\
\hline France & & 20 & 15 \\
\hline Malta & 45 & 35 & \\
\hline Italy & & 23 & \\
\hline Albania & 3 & 4 & \\
\hline Greece & & 10 & 12 \\
\hline Cyprus & 26 & 26 & 18 \\
\hline \multicolumn{4}{|l|}{ In Asia: } \\
\hline Turkey & 17 & 18 & 18 \\
\hline Syria & 83 & 83 & 99 \\
\hline Lebanon & 28 & 28 & 19 \\
\hline Palestine & 30 & 49 & 50 \\
\hline Israel & 100 & 87 & 101 \\
\hline \multicolumn{4}{|l|}{ In Africa: } \\
\hline Egypt & 95 & 95 & \\
\hline Libya & 793 & 711 & \\
\hline Tunisia & 66 & 57 & \\
\hline Algeria & 38 & 52 & \\
\hline Morocco & 38 & 43 & \\
\hline
\end{tabular}

Source: MDG

It is also interesting to notice the changes over two decades for the Millenium Development Goal Water Indicator (MDGWI). It is the proportion of total renewable water resources withdrawn (MDGWI). MDGWI is the total volume of groundwater and surface water withdrawn from their sources for human use (in the agricultural, municipal and industrial sectors), expressed as a percentage of the total actual renewable water resources. The terms water resources and water withdrawal are understood as freshwater resources and freshwater withdrawal. [Definition by FAO] As shown in Table 2, three thirds of the countries around the Mediterranean have an MDGWI higher than $20 \%$. Even though data is not available for all the countries around the Mediterranean, it is noted that the countries that are in the Mediterranean region currently are or will soon be facing severe water crises. When e MDGWI reaches above $20 \%$ water management becomes a concern in the country's economy (MDG, 2010; Angelakis et al., 2007).

What characterizes the Mediterranean countries, especially the ones in North Africa and the Middle East, is a severe water imbalance, especially in the summer months that cannot be shown by the Water Stress Index, the MDG or the TARWAR indicators alone. This imbalance is due to uneven precipitations, high summer temperatures, increased demands from tourism and continuous 
demands for irrigation in the summer months (Fatta and Anayiotou, 2007). Further to the above, the observed climate change has resulted in an increase in the extreme temperatures and in uneven precipitation.

It should be noted that in general it has been observed around the world that of the total volume of fresh water used in a country an estimated $65 \%$ is used for irrigation and withdrawals for industry are about $20 \%$ and those for municipal use are about $10 \%$ (Cosgrove and Rijsberman, 2000). From the data that is available for the Mediterranean countries the above percentages are on average higher for industrial and municipal water withdrawal in the Mediterranean countries, to $20 \%$ and $27 \%$ respectively (see Table 3 ). The latter stands as an additional indication that the countries around the Mediterranean are severely water stressed.

Table 3. Percentage of usage of water in Mediterranean countries

\begin{tabular}{|c|c|c|c|c|}
\hline & $\begin{array}{c}\text { Total } \\
\text { population } \\
(1000 \\
\text { inhab) }\end{array}$ & $\begin{array}{c}\text { Agricultural } \\
\text { water } \\
\text { withdrawal as } \\
\% \text { of total } \\
\text { water } \\
\text { withdrawal (\%) }\end{array}$ & $\begin{array}{c}\text { Industrial } \\
\text { water } \\
\text { withdrawal as } \\
\% \text { of total } \\
\text { water } \\
\text { withdrawal (\%) }\end{array}$ & $\begin{array}{c}\text { Municipal } \\
\text { water } \\
\text { withdrawal as } \\
\% \text { of total } \\
\text { withdrawal (\%) }\end{array}$ \\
\hline \multicolumn{5}{|l|}{ In Europe: } \\
\hline Spain & 45,638 & 60.51 & 21.74 & 17.76 \\
\hline France & 62,445 & 12.41 & 69.32 & 18.26 \\
\hline Slovania & 2,024 & 54.00 & 81.86 & 17.60 \\
\hline Croatia & 4,411 & 1.74 & 13.63 & 84.63 \\
\hline Greece & 11,327 & 89.30 & 1.76 & 8.93 \\
\hline Cyprus & 1,090 & 86.41 & 3.26 & 10,33 \\
\hline \multicolumn{5}{|l|}{ In Asia: } \\
\hline Turkey & 71,846 & 73.82 & 10.72 & 15.46 \\
\hline Syria & 20,054 & 87.53 & 3.67 & 8.80 \\
\hline Lebanon & 4,197 & 59.54 & 11.45 & 29.01 \\
\hline Palestine & 3,931 & 45.22 & 6.94 & 47.85 \\
\hline Israel & 7,261 & 57.58 & 5.79 & 36.44 \\
\hline AVERAGE & & 57.10 & 20.92 & 27.96 \\
\hline
\end{tabular}

Source: FAO (2009)

As described above, there is a real need for water in the majority of the countries around the Mediterranean, especially for municipal uses (on average it is three times more than the average around the world, or almost $28 \%$ compared to $10 \%$. The need for wastewater reuse around the Mediterranean would be considerable and it is worth investigating whether that need is enough of a driver for wastewater reuse adoption.

Water demand in the Mediterranean region is driven by: existing climate conditions as well as climate changes due to global warming, agricultural activities, urban activities, increases in tourism, as well as some industrial applications. Amongst the variety of long term strategies for alleviating the water shortage problem are: geographic transfer of water (transfer of water from areas of overabundance to areas experiencing scarcity), seawater pumping and desalination (removing salt from seawater and treating it to improve water quality), reduction of water consumption through better water management, rainwater harvesting, and wastewater treatment and reuse (Kalavrouziotis and Aslan-Alaton, 2008). The levels of TARWR Index for the Mediterranean countries is graphically depicted in Figure 1. 


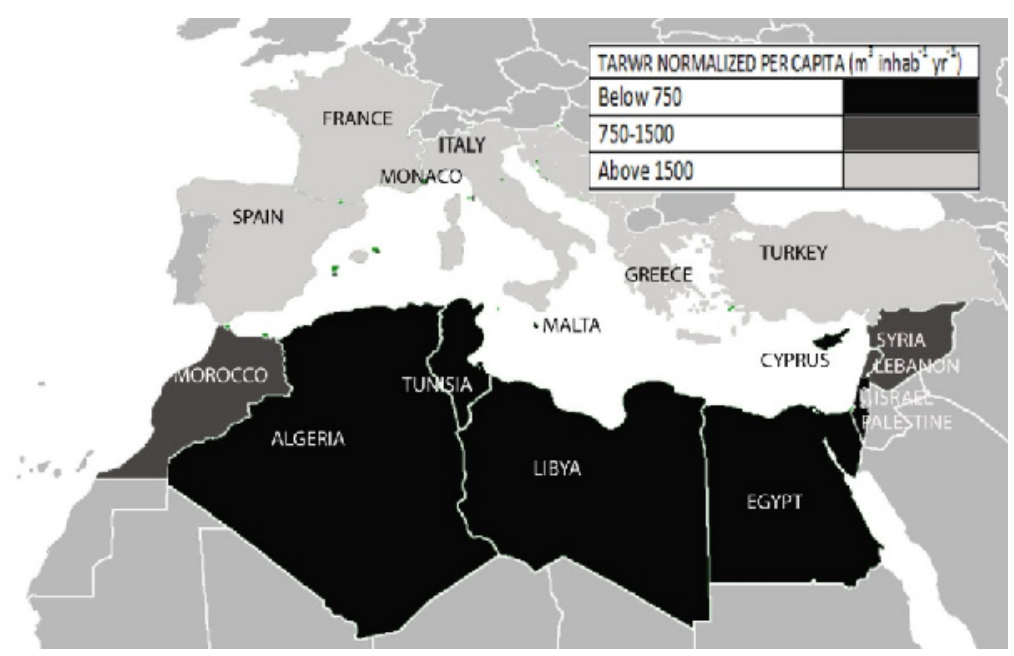

Figure 1. Map of countries around the Mediterranean highlighting water stress levels

The TARWR index and the MDGWI for each country were used for this depiction, darker color indicating a greater need in water. From Figure 1 it can be observed that there is a clear inequality in the available water supply for human consumption. Graphically it can be observed that it is the countries of the lower part of the Mediteranean that have the highest water needs, thus, those countries theoretically have the highest potential for water reclamation and reuse.

In this paper the regional needs within each country are not investigated although it could alter the water need profile for countries like Greece, which, due to geographical reasons, have a high diversity of local water indexes.

\section{WASTEWATER TREATMENT PRACTISES AND WATER REUSE CRITERIA}

Wasterwater reuse has traditionally been reserved for agricultural use (Angelakis et al., 1999; FattaKassinos et al., 2011; Pedrero et al., 2009). Reuse has been progressing to include urban and industrial applications around the world (USA, Australia, Japan). Countries around the Mediterranean have been progressing to include urban and industrial applications as well.

Conventional wastewater treatment process comprises of three distinct phases, each one yielding different effluent quality. Primary wastewater removes just settable solids from wastewater, and thus the quality of treated wastewater produced makes it inappropriate for reuse. Despite this, a large number of wastewater treatment plants, especially in the Asian and African part of Mediterranean comprises solely of primary treatment. In our present day, it is considered as the absolute minimum level of treatment before water is discharged. Some countries (Palestine, Syria, Libya) are still struggling to achieve this minimal level of wastewater treatment.

Secondary treatment refers to the removal of postulate and dissolved organic matter and to the oxidation of ammoniac nitrogen, by microorganisms. Some pathogens and hurtful substances are also removed during secondary treatment. Secondary treatment is the most common treatment practice in most Mediterranean countries. Most wastewater reuse applications that involve human contact are limited to water effluent from tertiary treatment. Such water can also be used for ground water recharging (Levine and Asano, 2004).

The applicability of reclaimed water for municipal and industrial applications is dependent upon the degree of wastewater treatment. As shown in Table 4 the applications relevant in this paper depend on tertiary treatment outflow. Table 4 is based on water quality reuse criteria set by the U.S. EPA for quality of reclaimed water (Duncan, 2004).

In this paper the applications for wastewater reuse that have been considered as municipal and industrial applications are landscape irrigation, industrial recycling and reuse, recreational and environmental uses, non potable municipal uses and potable municipal uses. Special mention is made for groundwater recharging. Table 4 shows the typical water reuse categories and applications. Cross referencing to the U.S.EPA guidelines the table was populated with acceptable reuse of effluents of primary, secondary and tertiary wastewater treatments (USEPA, 2004; WHO, 2006). 


\section{WASTEWATER REUSE PRACTICES AROUND THE MEDITERRANEAN FOCUSING ON MUNICIPAL AND INDUSTRIAL REUSE APPLICATIONS}

In this section each country explored is considered and an overview of water availability and needs, the wastewater reuse and recycling practices, and the guidelines of each country around wastewater recycling and reuse are considered.

Each country around the Mediterranean Basin has a different character as far as wastewater reuse for municipal and industrial applications is concerned. Countries around the Mediterranean have some of the most advanced profiles of water reuse around the world, equivalent to countries like the USA, Japan and Australia. Among the Mediterranean countries, Israel, Cyprus and Spain are leading in water reclamation and reuse technologies and applications. All countries are explored separately in terms of their reuse profile.

Data on the type of water reuse applications and the estimated total daily volume of reclaimed water in the Mediterranean countries have been tabulated and presented in Table 5.

\section{In Europe:}

Spain: Spain is at the Western edge of the European Mediterranean Countries, with one side on the Atlantic and the other on the Mediterranean. Spain has a population of close to 45 million people. Spain has a TARWR per capita of $2443 \mathrm{~m}^{3} \mathrm{yr}^{-1}$, a level that sustains food production and the MDGWI last reported in 2010 was $29 \%$. Spain on the side of the Atlantic experiences no water scarcity problems, whereas Spain on the side of the Mediterranean faces the arid and semi-arid climate of most Mediterranean countries.

Spain has a very good wastewater treatment infrastructure. In Spain, even though agricultural irrigation is the main driver of treated wastewater reuse, the trend is towards reuse for environmental purposes. In 2007 regulations were created for urban wastewater reuse in Spain. The Spanish water law (1985) and the Regulation for the Public Hydraulic Dominion (1986) are the main guidelines (Salgot and Pascual, 1996).

Reuse is taking place mostly in the coastal zones of the Mediterranean as well as other coastal regions, as well as around Madrid and Vitoria-Gaztei (Inglesias Estaban and Ortega de Miguel, 2008). Spain has acquired the capability of tertiary wastewater treatment and has been actively promoting the reuse of treated wastewater in municipal settings. Starting in July 2000 treated municipal wastewater has been used in applications like the golf course irrigation in Ginora, Spain (Candela et al., 2004). In Spain, municipal wastewaters is currently used in landscape irrigation, in the restoration of wetlands, firefighting, and for road washing. For example in the area of Costa Brava (Portbou, Colera, Port de la Selva and Cadaques), tertiary level outflow is used for landscape irrigation, firefighting, boat cleaning, and street cleaning. Table 6 shows an example of the distribution of wastewater in its reuse for the country of Spain, highlighting the $80 \%$ distribution for agriculture, $20 \%$ distribution for other uses. The total volume of wastewater reused in Spain in 2004 was $1,117,808 \mathrm{~m}^{3} \mathrm{~d}^{-1}$ (Iglesias, 2005).

France: France has a population of over 62 million people, and like Spain, has a coastline at the Atlantic and a coastline at the Mediterranean. France has a TARWR per capita of $3,379 \mathrm{~m}^{3} \mathrm{yr}^{-1}$, maintaining as a country a level that is able to sustain food production currently. Moreover the MDGWI last reported in 2005 for France is 15\%, meaning that the resources withdrawn for the country will be replenished. France though has two distinct characters, in the North where there is a high level of precipitation and in the South where there are pockets of arid and semi-arid Mediterranean climate.

The legal framework for water resources management, water supply and sanitation consists of two main laws: The Loi sur l'eau (Water Law) of 3 January 1992, and the Loi sur l'eau et les milieux aquatiques (Water and Aquatic Environment Law) of 30 December 2006. Guidelines for wastewater reuse have been established in 1991 in France and are based on the WHO guidelines, specifically the "Health guidelines for reuse, after treatment, of wastewater for crop and green spaces irrigation" (CSHPF), yet establish stricter guidelines for preventing human exposure through contact. The guidelines are almost too restrictive and thus prevent country-wide emergence of reuse (Faby et al., 1999). 
Table 4. Water Reuse Categories and Typical Applications

\begin{tabular}{|c|c|c|c|c|c|c|c|c|c|}
\hline \multirow{3}{*}{ Category } & \multirow{3}{*}{ Typical Application ${ }^{(1)}$} & \multicolumn{8}{|c|}{ Reuse of effluents: Methods of wastewater treatment and public health safeguards ${ }^{(2)}$} \\
\hline & & \multicolumn{6}{|c|}{ Outflow from secondary WW treatment } & \multicolumn{2}{|c|}{$\begin{array}{c}\text { Outflow from } \\
\text { tertiary WW } \\
\text { treatment }\end{array}$} \\
\hline & & 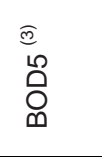 & 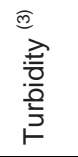 & $\begin{array}{l}\text { ले } \\
\text { क } \\
\mapsto\end{array}$ & 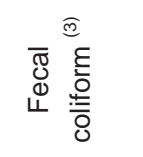 & $\frac{\sqrt{\frac{0}{0}}}{\frac{\pi}{0}}$ & 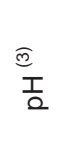 & 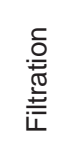 & 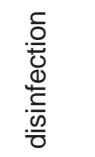 \\
\hline \multirow[t]{2}{*}{$\begin{array}{l}\text { Agricultural } \\
\text { irrigation }\end{array}$} & $\begin{array}{l}\text { Food Crop Irrigation } \\
\text { (consumed } \\
\text { uncooked) }\end{array}$ & $\begin{array}{l}\leq 10 \\
\mathrm{mg} \mathrm{L}^{-1}\end{array}$ & $\begin{array}{l}\leq 2 \\
\text { NTU }\end{array}$ & & $\begin{array}{l}\mathrm{ND} / 100 \\
\mathrm{~mL}\end{array}$ & $\begin{array}{l}1 \\
\mathrm{mg} \mathrm{L}^{-1}\end{array}$ & $6-9$ & Yes & Yes \\
\hline & $\begin{array}{l}\text { Non-food crops and } \\
\text { crops consumed after } \\
\text { processing }\end{array}$ & $\begin{array}{l}\leq 30 \\
\mathrm{mg} \mathrm{L}^{-1}\end{array}$ & - & $\begin{array}{l}\leq 30 \\
\mathrm{mg} \mathrm{L}^{-1}\end{array}$ & $\begin{array}{l}\leq 200 / 100 \\
\mathrm{~mL}\end{array}$ & $\begin{array}{l}1 \\
\mathrm{mg} \mathrm{L}^{-1}\end{array}$ & $6-9$ & No & No \\
\hline \multirow[t]{2}{*}{$\begin{array}{l}\text { Landscape } \\
\text { Irrigation }\end{array}$} & $\begin{array}{l}\text { Parks; School Yards; } \\
\text { Playgrounds }\end{array}$ & $\begin{array}{l}\leq 10 \\
\mathrm{mg} \mathrm{L}^{-1}\end{array}$ & $\begin{array}{l}\leq 2 \\
\text { NTU }\end{array}$ & & $\begin{array}{l}\mathrm{ND} / 100 \\
\mathrm{~mL}\end{array}$ & $\begin{array}{l}1 \\
\mathrm{mg} \mathrm{L}^{-1} \\
\end{array}$ & $6-9$ & Yes & yes \\
\hline & $\begin{array}{l}\text { Golf Courses; } \\
\text { Cemeteries; } \\
\text { Greenbelts; } \\
\text { Residential }\end{array}$ & $\begin{array}{l}\leq 30 \\
\mathrm{mg} \mathrm{L}^{-1}\end{array}$ & - & $\begin{array}{l}\leq 30 \\
\mathrm{mg} \mathrm{L}^{-1}\end{array}$ & $\begin{array}{l}\leq 200 \\
/ 100 \mathrm{~mL}\end{array}$ & $\begin{array}{l}1 \\
\mathrm{mg} \mathrm{L}^{-1}\end{array}$ & $6-9$ & Yes & yes \\
\hline $\begin{array}{l}\text { Industrial } \\
\text { Recycling } \\
\text { and Reuse }\end{array}$ & $\begin{array}{l}\text { Cooling Water ; Boiler } \\
\text { Feed; Process Water; } \\
\text { Heavy Construction }\end{array}$ & $\begin{array}{l}\leq 30 \\
\mathrm{mg} \mathrm{L}^{-1}\end{array}$ & - & $\begin{array}{l}\leq 30 \\
\mathrm{mg} \mathrm{L}^{-1}\end{array}$ & $\begin{array}{l}200 / 100 \\
\mathrm{~mL}\end{array}$ & - & - & Yes & yes \\
\hline $\begin{array}{l}\text { Groundwater } \\
\text { Recharge }\end{array}$ & $\begin{array}{l}\text { Groundwater } \\
\text { repleanishment; Salt } \\
\text { Water Intrusion } \\
\text { Control; Subsidence } \\
\text { Control }\end{array}$ & Site $\mathrm{sp}$ & c; spec & guidelin & do not exist & & & & \\
\hline $\begin{array}{l}\text { Recreational / } \\
\text { environmenta } \\
\text { I uses }\end{array}$ & $\begin{array}{l}\text { Lakes and ponds; } \\
\text { Marsh enhancement; } \\
\text { Stream flow } \\
\text { augmentation; } \\
\text { Fisheries; } \\
\text { Snowmaking }\end{array}$ & $\begin{array}{l}\leq 10 \\
\mathrm{mg} \mathrm{L}^{-1}\end{array}$ & $\begin{array}{l}\leq 2 \\
\text { NTU }\end{array}$ & & $\begin{array}{l}\mathrm{ND} / 100 \\
\mathrm{~mL}\end{array}$ & $\begin{array}{l}1 \\
\mathrm{mg} \mathrm{L}^{-1}\end{array}$ & $6-9$ & Yes & yes \\
\hline $\begin{array}{l}\text { Nonpotable } \\
\text { urban uses }\end{array}$ & $\begin{array}{l}\text { Fire protection; Air } \\
\text { conditioning; Toilet } \\
\text { Flushing }\end{array}$ & $\begin{array}{l}\leq 10 \\
\mathrm{mg} \mathrm{L}^{-1}\end{array}$ & $\begin{array}{l}\leq 2 \\
\text { NTU }\end{array}$ & & $\begin{array}{l}\mathrm{ND} / 100 \\
\mathrm{~mL}\end{array}$ & $\begin{array}{l}1 \\
\mathrm{mg} \mathrm{L}^{-1}\end{array}$ & $6-9$ & Yes & yes \\
\hline Potable uses & $\begin{array}{l}\text { Blending in water } \\
\text { supply reservoirs; } \\
\text { Blending in } \\
\text { groundwater; Direct } \\
\text { pipe to pipe water } \\
\text { supply }\end{array}$ & Meet re & ement & $r$ safe $d r$ & ing water; sp & cific guide & es do & t exist & \\
\hline
\end{tabular}

(1) Asano et al., 2007

(2) WHO, 2006; USEPA, 2004

(3) BOD5, biochemical oxygen demand; ND, not detected; NTU, nephelometric turbidity units; TSS, total suspended solids. 
Table 5. Water reuse in Mediterranean countries

\begin{tabular}{|c|c|c|c|c|}
\hline & $\begin{array}{l}\text { Total } \\
\text { population } \\
(1000 \text { inhab) } \\
2006 \text { data }^{(1)} \\
\text { (A) }\end{array}$ & $\begin{array}{l}\text { Total } \\
\text { volume of } \\
\text { treated } \\
\text { wastewater } \\
\text { reuse } \\
\left(\mathrm{m}^{3} \mathrm{~d}^{-1}\right)^{(2)} \\
\text { (B) }\end{array}$ & $\begin{array}{l}\text { Total } \\
\text { Volume of } \\
\text { treated } \\
\text { wastewater } \\
\text { per capita } \\
\text { (C) }=\text { (B) / } \\
\text { (A) }\end{array}$ & $\begin{array}{l}\text { Types of Wastewater Reuse } \\
\text { reported in different countries }{ }^{(3)}\end{array}$ \\
\hline \multicolumn{5}{|l|}{ In Europe: } \\
\hline Spain & 43,887 & $1,117,808$ & $25,470.14$ & $\begin{array}{l}\text { Agriculture, Municipal, } \\
\text { groundwater recharge, } \\
\text { environmental }\end{array}$ \\
\hline France & 61,330 & 19,178 & 312.70 & Agricultural, municipal, potable \\
\hline Monaco & 33 & $\mathrm{n} / \mathrm{a}$ & $\mathrm{n} / \mathrm{a}$ & - \\
\hline Malta & 405 & 10,960 & 27.06 & Agricultural, industrial \\
\hline Italy & 58,779 & 123,288 & $2,097.48$ & $\begin{array}{l}\text { Agricultural, municipal, } \\
\text { groundwater recharging, industrial }\end{array}$ \\
\hline Slovania & 2,001 & $\mathrm{n} / \mathrm{a}$ & $\mathrm{n} / \mathrm{a}$ & - \\
\hline Croatia & 4,556 & $\mathrm{n} / \mathrm{a}$ & $\mathrm{n} / \mathrm{a}$ & - \\
\hline Bosnia-Herz. & 3,926 & $\mathrm{n} / \mathrm{a}$ & $\mathrm{n} / \mathrm{a}$ & - \\
\hline Albania & 3,172 & $\mathrm{n} / \mathrm{a}$ & $\mathrm{n} / \mathrm{a}$ & - \\
\hline Greece & 11,123 & 28,000 & $2,517.31$ & Agriculture, industrial \\
\hline Cyprus & 846 & 68,493 & 80.96 & $\begin{array}{l}\text { Agricultural, municipal, } \\
\text { environmental }\end{array}$ \\
\hline \multicolumn{5}{|l|}{ In Asia: } \\
\hline Turkey & 73,922 & 136,986 & $1,853.12$ & $\begin{array}{l}\text { Agricultural, Municipal, } \\
\text { Environmental }\end{array}$ \\
\hline Syria & 19,408 & $1,014,000$ & $52,246.50$ & Agricultural, groundwater recharge \\
\hline Lebanon & 4,055 & 5,500 & $1,356.35$ & - \\
\hline Palestine & 3,889 & & $\mathrm{n} / \mathrm{a}$ & Agricultural, groundwater recharge \\
\hline Israel & 6,810 & $1,014,000$ & $148,898.68$ & $\begin{array}{l}\text { Agricultural, municipal, } \\
\text { groundwater recharge, } \\
\text { environmental }\end{array}$ \\
\hline \multicolumn{5}{|l|}{ In Africa: } \\
\hline Egypt & 74,166 & $1,780,821$ & $24,011.29$ & Agricultural, groundwater recharge \\
\hline Libya & 6,039 & 110,000 & $18,214.94$ & Agricultural \\
\hline Tunisia & 10,215 & 512,328 & $50,154.48$ & $\begin{array}{l}\text { Agricultural, municipal, } \\
\text { groundwater recharge, } \\
\text { environmental }\end{array}$ \\
\hline Algeria & 33,351 & - & $\mathrm{n} / \mathrm{a}$ & $\begin{array}{l}\text { Agricultural, municipal, } \\
\text { groundwater recharge, } \\
\text { environmental }\end{array}$ \\
\hline Morocco & 30,853 & 6,600 & 213.92 & Non treated wastewater reused \\
\hline $\begin{array}{ll}\text { (1) } & \text { Sol } \\
\text { (2) } & \text { Sol } \\
\text { (3) } & \text { Sol }\end{array}$ & $\begin{array}{l}\text { AO, } 2009 \\
\text { tudies refer } \\
\text { Asano and } J\end{array}$ & $\begin{array}{l}n \text { this } p \\
, 2008\end{array}$ & d U.S & \\
\hline
\end{tabular}


Table 6. Wastewater reuse in Spain (Inglesias, 2005)

\begin{tabular}{lllll}
\hline Uses & Year 2001 & \multicolumn{3}{l}{ Year 2004 } \\
\hline & $\begin{array}{l}\text { Volume } \\
\left(\mathrm{hm}^{3} \mathrm{y}^{-1}\right)\end{array}$ & $\%$ & $\begin{array}{l}\text { Volume } \\
\left(\mathrm{hm}^{3} \mathrm{y}^{-1}\right)\end{array}$ & $\%$ \\
\hline Irrigation & 284.9 & 82.3 & 323.0 & 79.2 \\
\hline Municipal Uses & 24.0 & 7.0 & 25.0 & 6.0 \\
\hline $\begin{array}{l}\text { Recreational use } \\
\text { golf courses }\end{array}$ & 20.6 & 6.0 & 25.0 & 6.0 \\
\hline Industrial uses & 2.5 & 0.7 & 3.0 & 0.7 \\
\hline Ecological uses & 14.0 & 4.0 & 24.0 & 6.0 \\
\hline Total & 346.0 & 100.0 & 408.0 & 100.0 \\
\hline
\end{tabular}

There are over 17,500 wastewater treatment plants in existence in France, most of them with a capacity lower than 2,000 PE. France has been reusing wastewater for agriculture for over a century, especially around the Paris area. The reuse of treated wastewater is evident, mostly in the South, around the Mediterranean. Landscape irrigation is currently the main demand of water reuse in France. The guidelines, almost too restrictive, coupled with overzealous local compliance standards, often even exceeding these guidelines, taper down the possible extensive country-wide reuse of urban and industrial applications. Selected examples of municipal wastewater reuse for industrial and urban reuse include applications in Annecy, for toilet flushing, and industrial operations in Renault factories (Lazarova et al., 2003; Liaw et al., 2006). The total volume of wastewater reused in France in 2004 was $19,178 \mathrm{~m}^{3} \mathrm{~d}^{-1}$.

Monaco: Monaco because of its particularly small size and its high population density has not set independent wastewater reuse as a country priority. Due to its particular geographical inclusion inside France, the conditions are similar to those of the Mediterranean region of France.

Malta: Malta, an island country, has a population of a bit over 415 thousand people. The country has been long experiencing severe water stress. Currently with a TARWR of $122 \mathrm{~m}^{3}$ / capita / year and the MDGWI last reported in 2000 was $72 \%$ (note that in 1990 it was 350\%), Malta is facing the most severe natural wastewater scarcity, compared to the rest of Mediterranean countries. Malta has been characterized as an area of drought by the European Union. Malta does not have any permanent streams, lakes or rivers.

Wastewater reuse practices in Malta are governed by legislation number 340 of 2001 and came into force in 2004 (Matla EPA, 2004).

The water supply problem has always been high up in the priority list of the authorities governing these islands. Wastewater reuse for irrigation has been contemplated as early as 1884 . The Sant' Antnin Sewage Treatment Plant (SASTP) was commissioned in 1983, and since then it has been producing water for irrigation (Angelakis, 2003b). The SASTP was designed to augment the irrigated area on these Islands by 500 ha, since water is indeed scarce. During 1990, plant effluent started to be used at the nearby industrial estate for the washing of garments. SASTP is currently being upgraded to increase reclaimed water production from $7,000 \mathrm{~m}^{3} \mathrm{~d}^{-1}$ to $12,000 \mathrm{~m}^{3} \mathrm{~d}^{-1}$ (Gauci, 1993).

Italy: Italy has a population of over 60 million people and has a TARWR per capita of $3175 \mathrm{~m}^{3} \mathrm{yr}^{-1}$. Moreover the MDGWI last reported in 2000 for Italy was $20 \%$. Yet, Italy has clearly two distinct geographies: in the North, where water is plentiful, and in the South, where the country is arid.

Regulations in place in Italy have been evolving to include a more relaxed set of restrictions, thus facilitating reuse. A new set of regulations has been adopted in 2003. In Italy wastewater discharge is regulated by legislative decree $n 152$ of 2006, implementing the provisions of EU Directive 60/2000, Italian legislation (General Technical Standards, G.U. 21.2.77)

In Italy a high number of wastewater treatment plants, over 10,000, are in operation and a significant number utilizes tertiary treatment, primarily for treated effluent discharge to rivers. In a limited scale, applications such as landscaping and fire protection have been incorporated in the wastewater reuse 
gamut (Barbagallo et al., 2001) Wastewater reuse for municipal and industrial applications is mostly in the planning phases. In Italy, the total volume of municipal wastewater is about $2400 \mathrm{Mm}^{3} \mathrm{yr}^{-1}$ (Angelakis et al., 2003a).

Albania, Bosnia and Herzegovina, Croatia, Montenegro, Slovania: The above mentioned countries have high TARWR reported $\left(13,060,9,552,23,917 \mathrm{~m}^{3} \mathrm{yr}^{-1}\right.$ capita $\left.^{-1}\right)$ so they are not facing the urgent need to protect their water sources. Most are also newly formed countries that present instabilities in their formation still. There has been little progress made in those countries regarding wastewater treatment and recycling. Since the end of the war because there is an absence of sewage networks and of basic infrastructure the possibility for wastewater treatment and reuse has not been universally established yet. There has been some efforts at establishing guidelines that have not come to fruition yet (Kamizoulis et al., 2005).

Greece: Greece has a population over 11 million. Greece has a TARWR of 6,596 $\mathrm{m}^{3} \mathrm{yr}^{-1} \mathrm{capita}^{-1}$ and the MDGWI last reported in 2005 was 12\%. The Water stress that this data shows is low. Yet Greece is mostly a mountainous country with uneven water distribution. This unbalance creates water demand in mainland Greece as well. The Greek islands though are often completely devoid of water resources and in the summer months due to tourism have water brought in by boats. Due to this particular geography Greece has a high water stress level in certain regions only. Greece has an uneven water supply with shortages in the summer months so reuse is of interest (Gikas and Tchobanoglous, 2009; Gikas and Angelakis, 2009).

Wastewater treatment regulations were created in Greece under ministry decree 1811B/29-9-1999 in 1961, 1982 and 1999 (Andreadakis et al., 2001) and upadated in 2002 to reflect European Directive 2000/60. Regulations for wastewater reuse were established through a governmental degree in 2008, and were updated in 2011 (Greek MECC)

All towns with population above 2000 people are served by wastewater treatment plants, or wastewater treatment plants are under construction (SSW, 2009). Wastewater reclamation and reused is practiced in a few areas (e.g.: Thessalokiki, Chalkis, Cherssonisos) and in hotels primarily located on islands. It is expected that water reuse applications will be increased substantially in the near future, after the implementation of the universal water reuse quality criteria (Greek MECC).

Cyprus: Cyprus is a Mediterranean island with a population of just over 1 million people. Cyprus has a TARWR per capita of $715.6 \mathrm{~m}^{3} \mathrm{yr}^{-1}$, classifying Cyprus as a country with no sustainable food production, according to WHO criteria. Moreover the MDGWI last reported in 2010 for Cyprus was $18.4 \%$, meaning that the water withdrawn for consumption in the island cannot be replenished. In Cyprus the average annual precipitation is about $500 \mathrm{~mm}, 80 \%$ of which is estimated to be lost by evapotranspiration. Cyprus has been characterized as a drought area by the European Union (Papaiacovou, 2001).

Standards and guidelines for reuse have been established in 2005, focusing on irrigation and environmental protection and were updated in 2011 under law 147/2011 and ministerial decree 50/2011 (Angelakis et al., 2007; Cyprus MoA).

Cyprus currently has 25 wastewater recycling plants in operation. Current total water use is $300 \mathrm{Mm}^{3}$ $\mathrm{yr}^{-1}$, over $20 \%$ used for applications other than agricultural irrigation (Fatta et al., 2005). Tertiary treated effluent is used in golf courses in the area around Limassol (Papaiakovou, 2001). Wastewater is also reused in landscape irrigation (Fatta et al., 2005).

\section{In Asia:}

Turkey: Turkey has a population of almost 72 million. Turkey has a TARWR per capita of 2973 $\mathrm{m}^{3} \mathrm{yr}^{-1}$, maintaining as a country a level that is able to sustain food production currently. Moreover the MDGWI last reported in 2005 for Turkey is $18 \%$, meaning that the resources withdrawn for the country overall are safely being replenished.

Guidelines in Turkey for wastewater reuse even in agriculture have been recently adopted (ArslanAlton et al., 2007). 
Turkey has 129 plants in operation and approximately $45 \%$ of the country's population is being served (Fatta et al., 2005). The wastewater treatment effluent is mostly discharged in rivers and the sea. It is also being used for irrigation purposes and in forestry. Wastewater reuse for municipal and industrial applications is currently under consideration in Turkey.

Syria: The Syria has a population of over 20 million. Syria has a small coast on the Mediterranean and is mostly facing the harsh desert conditions of the Middle East region. Syria has a TARWR per capita of $837 \mathrm{~m}^{3} \mathrm{yr}^{-1}$, putting Syria as a country dangerously close to $750 \mathrm{~m}^{3} \mathrm{yr}^{-1}$, the level below which food production cannot be sustained. Already though it is "water stressed". Moreover the MDGWI last reported in 2010 for Syria was $99 \%$, meaning that most of the water is withdrawn from the country's resources.

Guidelines in Syria for wastewater reuse even in agriculture are being considered (Baza, 2003).

The wastewater volume reused in Syria, due to the country's severe water scarcity characteristics is large in absolute terms; the output quality is still limited though to secondary treatment and sometimes even primary treatment. Particular health concern poses the reuse of untreated wastewater for irrigation (Saqer, 2005). Several wastewater treatment plants have been constructed, especially around the bigger cities (Damascus, Aleppo, a.o.) with a potential $400 \mathrm{~m}^{3} \mathrm{yr}^{-1}$ available for reuse mostly for irrigation. Because of the alarming health conditions caused by the lack of wastewater treatment a number of wastewater treatment plants are in construction by the Syrian government (Bazza, 2003).

Lebanon: Lebanon has a population of over 4 million. Lebanon has a large percentage of the country on the Mediterranean Sea and its climate is more temperate only facing arid conditions. Lebanon has a TARWR per capita of $1073 \mathrm{~m}^{3} \mathrm{yr}^{-1}$, showing that Lebanon is "water stressed". Moreover the MDGWI last reported in 2005 for Lebanon was 19\%.

Lenanese guidelines prohibit the reuse of treated wastewater for the growth of crops consumed by humans. Also guidelines for discharge of treated effluents into the sea and surface waters are in existence. New Guidelines in Lebanon for wastewater reuse even in agriculture are being considered (Bdour et al., 2009)

The only wastewater treatment plant generating water for irrigation, is Baalbak WWTP where 12000 $\mathrm{m} 3 /$ day are generated (Kamizoulis et al., 2005). The potential wastewater volume in Lebanon is $640.000 \mathrm{~m}^{3}$, planned to be discharged at sea. Because of the country's relative water scarcity possibilities for reuse of the wastewater treatment plants outflow are being considered (Ayoub and Chammas, 2006).

Palestine: Palestine (West Bank and Gaza Strip) has a population of almost 4 million. Palestine has a TARWR per capita of $212 \mathrm{~m}^{3} \mathrm{yr}^{-1}$, putting Palestine as a country well below $750 \mathrm{~m}^{3} \mathrm{yr}^{-1}$, the level below which food production cannot be sustained. the MDGWI last reported in 2005 for Palestine was $50 \%$, meaning that resources are withdrawn that cannot be replenished.

The reuse of reclaimed wastewater in Palestine is a major priority confirmed in the Palestinian Water Policy reviewed by the PWA and the Ministry of Agriculture. Guidelines were established by the government for wastewater treatment based on the standards proposed by WHO, although they have not yet been adopted or enforced (WHO, 2006; Mogheir et al., 2005). It is important to note that in the Middle East and West African Region some Muslims believe that the use of treated wastewater is impure and as so forbidden by Islam. Even though in 1978 a fatwa was issued decreeing that treated wastewater could be considered pure with proper treatment, some people still object to wastewater reuse on religious grounds (McNeil et al., 2009).

Sewage collection is limited to urban centers about $35 \%$ in West Bank and $65 \%$ in Gaza are connected to the sewerage system. The volume of wastewater generated is $50 \mathrm{MCM} \mathrm{yr}^{-1}$ (29 in the West Bank and 21 in Gaza). Of this volume only $1.4 \mathrm{MCM} \mathrm{yr}^{-1}$ is treated in the West Bank. Agricultural use of treated effluents was initially intended in Jabaliah and Gaza City. However implementation failed due to lack of funds and rejection by the farmers of treated wastewater reuse due to cultural and religious beliefs. In Palestine have been constructed a few pilot small-scale wastewater reuse projects. (EMWPC, 2004; EU, 2004). 
Israel: Israel has a population of over 7 million. Israel in the North is subject to a Mediterranean climate, and in the Sotuh faces arid climatic conditions. Israel has a TARWR per capita of $245 \mathrm{~m}^{3} \mathrm{yr}^{-1}$, putting Israel as a country well below $750 \mathrm{~m}^{3} \mathrm{yr}^{-1}$, the level below which food production cannot be sustained. Moreover the MDGWI last reported in 2005 for Israel was $101 \%$ an acute shortage of water throughout the country and repeated water droughts.

Since 1959 the law defines treated wastewater as an integral part of the water resources for the country. Guidelines for wastewater reuse were established in the seventies after an outbreak of cholera in Jerusalem from untreated wastewater reuse. The guidelines developed in Israel are based on practical applications and establish a precedent for the rest of the world. Regulations and guidelines are updated continuously to reflect findings from current research.

Israel is a model though for the world in terms of its desalination and wastewater recycling and reuse programs. The desert has been transformed through the work of men into fertile land. $75 \%$ of treated wastewater is reused, primarily used for agricultural irrigation. The tendency for industry reuse is to recycle the on-site water, as can be seen at the Haifa Oil Refineries, reusing approximately $2.5 \mathrm{MCM}$ $\mathrm{yr}^{-1}$ of treated petrochemical wastewater for cooling purposes. The Dan Region Project provides 0.8 MCM $\mathrm{yr}^{-1}$ of its high quality effluent to several industries along its way. Even though the technology is available and the plants capable of supplying the necessary volume for urban reuses, public acceptance delays possible applications into the far future (Fiedler and Lahav, 2006).

\begin{abstract}
Africa:
Egypt: Egypt has a population of almost 80 million. Egypt's North borders the Mediterranean while the country's main water supply is from the Nile River. Egypt has a TARWR per capita of $718 \mathrm{~m}^{3} \mathrm{yr}^{-1}$, so it is already apparent that food production cannot be sustained. Moreover the MDGWI last reported in 2000 for Egypt was 113\%, meaning that most of the resources are withdrawn from the country's resources. Indeed $96 \%$ of the country is desert, rains are rare even in the winter and occur only in the north. Oasis and dwells are small and cannot supply for the needs of the areas surrounding them. The country relies on the water carried by the Nile River.
\end{abstract}

No reuse guidelines have been established. The 1984 martial law regulation prohibits reuse of wastewater unless treated to established standards, being drafted (USEPA, 2004). Law 93/1962 regulates wastewater disposal and designates the responsibility of constructing public wastewater systems to the Ministry of Housing which is also responsible for issuance of permits regulating wastewater discharge into public sewerage networks or into the environment. The Ministry of Health determines the regulatory standards. The 1989 World Health Organization Guidelines and the newly issued Ministerial Decree 44/2000 (by the Ministry of Housing, Utility, and Urban Communities) set the water quality requirements for unrestricted and restricted irrigation. However, compliance with these water quality standards remains to be implemented (Allam and Allam, 2007).

The estimated volume of treated wastewater is 4,930 million $\mathrm{m}^{3} \mathrm{yr}^{-1}$, with 22 wastewater treatment plants, and about 150 under construction, located mainly in the major cities, such as Cairo and Alexandria. The total capacity of the wastewater treatment plants is about 1.752 billion $\mathrm{m}^{3} \mathrm{yr}^{-1}$.

Libya: The Libya has a population of over 6 million. Libya has a TARWR per capita of $95.8 \mathrm{~m}^{3} \mathrm{yr}^{-1}$ the lowest in all Mediterranean countries, and well below $750 \mathrm{~m}^{3} \mathrm{yr}^{-1}$ so it is already apparent that food production cannot be sustained. Moreover the MDGWI last reported in 200 for Libya is $793 \%$, meaning that Libya has already withdrawn all available resources from its territory.

Despite the dire need of the country for water there are no guidelines for wastewater reuse in Libya. Less than $10 \%$ of the wastewater generated in Libya $\left(546 \mathrm{Mm}^{3} \mathrm{yr}^{-1}\right.$ in 1999) is treated $\left(40 \mathrm{Mm}^{3} \mathrm{yr}^{-1}\right)$ and it is reused in restricted agricultural applications only (Asano et al., 2007).

Tunisia: Tunisia has a population of over 10 million. Tunisia has an arid to semi-arid climate. Tunisia has a TARWR per capita of $443 \mathrm{~m}^{3} \mathrm{yr}^{-1}$, well below $750 \mathrm{~m}^{3} \mathrm{yr}^{-1}$ so it is already apparent that food production cannot be sustained. Moreover the MDGWI last reported in 2001 for Tunisia was 57\%, meaning that Tunisia is going to be facing severe water shortage problems in the forthcoming years and decades. 
Tunisia has a long history of wastewater reclamation and reuse for irrigation. Guidelines were established in the eighties. Tunisia is among the first countries in the Mediterranean Basin to have established and implemented a wastewater reuse policy.

Tunisian farmers are not only reusing wastewater they are also willing to pay for it. Therefore some of the operational costs are covered. Other applications in Tunisia include golf course irrigation, green belts and hotel landscaping. Lastly wastewater is used for recharging storage reservoir and coastal aquifers reservoirs (Bahri and Brissaud, 1996).

Algeria: Algeria has a population of almost 35 million. Algeria has a TARWR per capita of $334 \mathrm{~m}^{3} \mathrm{yr}^{-1}$, well below $750 \mathrm{~m}^{3} \mathrm{yr}^{-1}$ so it is already apparent that food production cannot be sustained. Moreover the MDGWI last reported in 2000 for Algeria was 52\%,meaning that Algeria is going to be facing severe water shortage problems in the forthcoming years and decades.

Algerian law prohibits absolutely the reuse of wastewater for irrigation of crops that might be eaten raw, it allows though irrigation of crops fodder crops, pasture and trees (Kamizoulis et al., 2005; Algerian MARD).

In Algeria, the volume of municipal wastewater in 1985 was approximately $660 \mathrm{Mm}^{3}$ projected to reach $1,500 \mathrm{Mm}^{3}$ by 2010 from 15 treatment plants. The Algerian authorities have initiated a program that enables the rehabilitation of 28 treatment stations, the construction of new wastewater treatment stations and wastewater stabilization ponds. For the success of the program, an efficient follow up and periodic evaluation is necessary to safeguard the water resources and the environment from negative impacts of pollution (Kalavrouziotis and Arslan-Alaton, 2008).

Morocco: Morocco has a population of over 31 million. Morocco is an arid semi-barren country. Morocco has a TARWR per capita of $916 \mathrm{~m}^{3} \mathrm{yr}^{-1}$, making the country "water stressed". Morocco's Atlantic Coast provides some moisture and this is why the country's conditions are slightly better than its neighbors. The MDGWI last reported in 2000 for Morocco was 44\%. Despite abundant precipitation due to Morocco's proximity to the Atlantic Ocean, Morocco is an arid to semi-arid country.

Legislation was established in 1995 regarding a national water policy. Morocco does not yet have any specific guidelines for wastewater reuse and refers to the WHO recommendations (Fatta and Anayiotou, 2007; USEPA, 2004).

Morocco does not have a clear wastewater reuse practice. Most wastewater treatment plants are secondary plants (Fatta et al., 2005). The volume of collected municipal wastewater was estimated at $380 \mathrm{Mm}^{3} \mathrm{yr}^{-1}$ in $1998,500 \mathrm{Mm}^{3} \mathrm{yr}^{-1}$ in 2000 , and is expected to reach $700 \mathrm{Mm}^{3} \mathrm{yr}^{-1}$ by $2020.58 \%$ of the treated wastewater is discharged into the sea and $52 \%$ into rivers. $85 \%$ of the produced sewage does not undergo treatment. There are 69 wastewater treatment plants in Morocco and only 29 or $40 \%$ remain in operation whereas the rest are either out of order, or non-completed. Current uses of treated wastewater are primarily agriculture, and in a very limited way landscaping and industrial uses, and cement. Potential future uses include aquaculture, agro-forestry, environmental reuse and industrial reuse (Kalavrouziotis and Arslan-Alaton, 2008; Choukr-Allah, 2005).

\section{OVERVIEW OF WASTERWATER REUSE PRACTICES IN MEDITERRANEAN COUNTRIES FOCUSING ON POLICIES, GUIDELINES AND REGULATIONS}

In this section the data from the Mediterranean Countries is reviewed in order to draw conclusions for the reuse practices and efficiency of wastewater reuse guidelines.

The overall water stress level, as shown by the water stress index and the combination of the TARWR and MDG indicators, in the European part of the Mediterranean is not as high as in the Asian and African parts. What drives the adoption of wastewater treatment and the push towards reuse is only in part guidelines set up by the European Union through economic measures and penalties imposed to the member states in the South of Europe. The latter shows that guidelines can be as important a driver for change as is the underlying need created by elevated water stress (Angelakis et al., 2007). Water need is of course the main reason for wastewater recycling and reuse. It Mediterranean countries it is observed a tendency for adoption of wastewater reuse guidelines or for the revision of existing guidelines (Bdour et al., 2009). 
From section 1, it can be concluded that water stress does not seem to be the indicator for the adoption of wastewater reuse and recycling in countries around the Mediterranean basin, since the countries that have the most severe water scarcity (Figure 1) are the ones that have the fewest applications for wastewater recycling and reuse.

Table 7. Current Regulations in selected Mediterranean Countries

\begin{tabular}{lll}
\hline & $\begin{array}{l}\text { Regulations } \\
\text { in place }\end{array}$ & Date Regulations Adopted \\
\hline In Europe: & yes & 1985,2007 \\
\hline Spain & yes & 1999,2003 \\
\hline France & yes & 1983,2001 \\
\hline Malta & yes & 2003 \\
\hline Italy & yes & 2004,2011 \\
\hline Greece & yes & 2005 \\
\hline Cyprus & & \\
\hline In Asia: & yes & considered \\
\hline Turkey & no & considered \\
\hline Syria & no & $\begin{array}{l}\text { Reuse for human consumption prohibited, } \\
\text { reuse for crops considered }\end{array}$ \\
\hline Lebanon & yes & 2001 \\
\hline Palestine & yes & 1959 \\
\hline Israel & & \\
\hline In Africa: & no & 1984,1989 WHO, Martial law prohibits \\
\hline Egypt & reuse \\
\hline Libya & no & \\
\hline Tunisia & yes & 1980 \\
\hline Algeria & no & Reuse prohibited \\
\hline Morocco & yes & 1995, WHO \\
\hline
\end{tabular}

Table 7 summarizes in which Mediterranean countries exist water reuse regulations and the relative year that those regulations were adopted.

Adoption of wastewater reuse practices does not seem to be independent of the adoption of legislature in each country, although the stage of development of the country itself does play a role in the adoption of wastewater reuse practices. In European Union (EU) countries, because of the financial incentives associated with EU guidelines established in member states, a push for development can be observed. In the non-EU countries the stage of adoption is linked to the state of economic development of the country. In some instances religious concerns prohibit reuse.

\section{CONCLUSIONS:}

After considering multiple parameters associated with adoption of municipal and industrial wastewater reuse, such as water supply and scarcity, country and regional parameters, as well as possible applications, we note that adoption is accelerated in countries that have stronger economies and higher water needs. This development is fueled by favorable guidelines and regulations, conversely it is hindered by prohibitive guidelines and regulations put in place for cultural and religious reasons for example. Wastewater reuse for municipal and industrial applications so far remains a whimsical game of culture, perception, religion, available technology and politics.

An increasing trend in wastewater treatment plant construction and planning is evident in almost all the countries of the Mediterranean region. In addition, reuse water standards are in the process of being developed in a way that will clearly take into account the local conditions while reasonably safeguarding the public health.

Wastewater reuse for municipal and industrial applications in Mediterranean countries remains at the beginning stages of adoption

The potential of improvement is open in most Mediterranean Countries as far as wastewater reuse for urban and industrial applications is concerned. 


\section{REFERENCES}

1. Algerian Ministry of Agriculture and Rural Development (MARD) Executive Decree $n^{\circ}$ 09-311 of 4 Chaoual 1430 reporting 23 sep 2009 changing and completing decree $n^{\circ}$ 87-15 of 13 Jan 1987 creating national institute of lands, watering and drainage (I.N.S.I.D), JORA №56 of 30 Sep 2009 (in French).

2. Allam M. and Allam G. (2007) Water Resources in Egypt: Future Challenges and Opportunities, Water International, 32(2), 205-218.

3. Angelakis A., Marecos Do Monte M., Bontoux L. and Asano T. (1999) The status of wastewater reuse practices in the Mediterranean Basin: Need for Guidelines, Wat. Res, 33(10), 2201-2217.

4. Angelakis A.N., (2003a). Wastewater Recycling and Reuse in EUREAU Countries: With Emphasis on Criteria Used. Ciclo di Convegni, Anno Internazionale dell'Acqua 2003, Servizi Idrici: problemi e soluzioni. Federgasacqua, Rome, Italy, pp. 363-382.

5. Angelakis A.N., (2003b) Wastewater Recycling and Reuse in Malta. FAO, Rome, Italy, pp. viii, 175.

6. Angelakis A.N., Durham B., Marecos Do Monte M.H.F., Salgot M., Witgens T. and Thoeye C. (2007) Wastewater Recycling and Reuse in Eureau Countries, Three Valleys Witness Session.

7. Andreadakis A., Gavalaki E., Mamais D. and Tzimas A. (2001) Watewater reuse criteria in Greece, Proceedings of the $7^{\text {th }}$ International Conference on Environmental Science and Technology, Ermoupolis, Syros Island, pp 7-14

8. Arslan-Alaton I., Tanik A., Ovez S., Iskender G., Gurel M. and Orhon D. (2007) Reuse Potential of wastewater treatment plant effluents in Turkey: A case study on selected plants, Desalination, 215, 159-165

9. Asano T., Burton F., Leverenz H., Tsuchihashi R. and Tchobanoglous G. (2007) Water Reuse Issues, Technologies, and Applications. Medcalf \& Eddy / AECOM / Mc-Graw Hill, New York

10. Asano T. and Jimenez B. (2008) Water reuse: an international survey of current practice, issues and needs. IWA Publishing, London UK.

11. Ayoub G.M. and Chammas D. (2006) Potential for wastewater reclamation and reuse in Lebanon International Journal of Environment and Pollution, 28(1/2), 16 - 32

12. Bahri A. and Brisaud F. (1996) Wasterwater Reuse in Tunisia: assessing a national policy, Water Science and Technology, 33(10-11), 87-94

13. Barbagallo S., Cirelli G.L. and Indelicato S. (2001) Wasterwater Reuse in Italy, Water Science and Technology, 43(10), 43-50

14. Baza M. (2003) Wastewater recycling and reuse in the Near East Region: Experiences and Issues, Water Science and Technology: Water Supply, 3(4), 33-50

15. Bdour A., Hamdi M. and Tarawneh Z. (2009) Perspectives on sustainable wastewater treatment technologies and reuse options in the urban areas of the Mediterranean region, Desalination, 237(13), 162-174.

16. Candela L., Fabergat S. and Josa A. (2004) Treated urban wastewater re-use for irrigation of a golf course and impacts on soil and groundwater: Wastewater Re-use and Groundwater Quality (Proceedings of symposium HS04 held during IUGG2003 at Sapporo, July 2003), IAHS Publ. 285.

17. Choukr-Allah R. (2005) Wastewater Treatment and Reuse in Morocco: Situations and Perspectives (working paper).

18. Cosgrove W.J. and Rijsberman F.R. (2000) World Water Vision: Making Water Everybody's Business, Earthscan Publications, London.

19. Cyprus Ministry of Agriculture, Natural Resources and Environment (MoA) N.122/2012 "About Water Management and Water Protection enarmonization of laws from 2004 to 2012" http://www.moa.gov.cy/moa/wdd/Wdd.nsf/index gr/index gr?OpenDocument

20. Duncan M. (2004) Domestic Wastewater Treatment in Developing Countries, Earthscan, London.

21. EM Water Project Country study (EMWPC). (2004) Prospects of Efficient Wastewater Management and Water Reuse in Palestine. Adelphi Research, Berlin, Germany

22. EU (2004) Prospects of Eficient Wastewater Management and Water Reuse in Palestine, document Insitute for Water Studies, Birzeit University, Wet Bank, Palestine pp 1-54.

23. EUWI European Union Water Initiative Mediterranean, Water Scarcity and Drought Working Group (2008) Mediterranean Water Scarcity and Drought, Final Report, European Commission www.emwis.net/topics/WaterScarcity (accessed on January $10^{\text {th }}, 2010$ )

24. Faby J.A., Brissaud F. and Bontoux J. (1999) Wastewater reuse in France: Water quality standards and Wastewater Treatment Technologies, Wat. Sci. Tech., 40(4-5), 37-42.

25. Fatta D., Arslan Alaton I., Gokcay C., Rusan M., Mountadar M. and Papadopoulos A. (2005) Wastewater Reuse: Problems and Challenges in Cyprus, Turkey, Jordan and Morocco, European Water, 11/12, 63-69. 
26. Fatta D. and Anayiotou S. (2007) MEDAWARE project for wastewater reuse in the Mediterranean countries, Desalination, 211, 34-47.

27. Fatta-Kassinos D., Kalavrouziotis I.K., Koukoulakis P. H. and Vasquez M.I. (2011) The risks associated with wastewater reuse and xenobiotics in the agroecological environment, The Science of the Total Environment, 409, 3555-3563.

28. Fiedler E. and Lahav O. (2006) Centralized urban wastewater reuse: what is the public attitude?, Water Science and Technology, 54(6-7), 423-430.

29. FAO, Food and Agriculture Organization of the United Nations (2009) Databases. Water Resources by Country/ Territory and by inhabitant, and MDG Water Indicator. http://www.fao.org/ (accessed February 24, 2010)

30. Gauci V. (1993) Supply of Irrigation Water in a Semi-Arid Area, Options Mediterranees Ser B/ N 7 Malta (Food Agriculture fisheries and the environment) pp 83-91

31. Gikas P. and Tchobanoglous G. (2009) Sustainable Use of Water in the Aegean Islands, Journal of Environmental Management, 90, 2601-2611.

32. Gikas P. and Angelakis A.N. (2009) Water Resources Management in Crete and in the Aegean Islands, with Emphasis on the Utilization of Non-Conventional Water Sources, Desalination, 248, 1049-1064.

33. Greek ministry of the Environment and Climate Change, Special Secretariat for Water (MECC EGY) "Determination of rules and regulations governing wastewater recycling and reuse and other regulations" (8 March 2011) (in Greek)

34. Iglesias E.R. (2005), Existing and proposed scenarios for wastewater reuse and recycling in Spain Workshop: The integration of reclaimed water in water resource management, Lloret de Mar, Costa Brava, Girona, October 2005 (In Spanish).

35. Iglesias A., Garrote L., Flores F., Moneo M. (2007) Challenges to Manage the Risk of Water Scarcity and Climate Change in the Mediterranean; Water Resources Management, 21, 775-788.

36. Inglesias E.R., Ortega de Miguel E. (2008) Present and Future of wastewater reuse in Spain, Desalination, 218(1-3), 105-119.

37. Italy Ministry of the Environment and Territory (MET) (2000) "Implementation of Water Framework Directive 60/2000" http://www.direttivaacque.minambiente.it/documenti/Direttiva_2000-60-CE.pdf (in Italian).

38. Kalavrouziotis I. and Arslan-Alaton I. (2008) Reuse of urban wastewater and sewage sludge in the Mediterranean countries: Case Studies from Greece and Turkey, Fresenius PSP, 17(6), 295-307.

39. Kamizoulis G., Bahri A., Brissaud F. and Angelakis A. (2005) Wastewater recycling and use practices in the Mediterranean region: Recommended Guidelines, Water International, 841-854.

40. Lazarova V, Hills S, Bicks R. (2003) Using recycled water for non-potable, urban uses: a review with particular reference to toilet flushing, Water Science and Technology, 3(4), 69-77.

41. Levine A., Asano T. (2004) Recovering Sustainable Water from Wastewater, Environmental Science and Technology, 38, 201A-208A.

42. Liaw C.H., Chen L.C. and Chan L.M. (2006) Industrial Water Demand with Water Reuse, Journal of the American Water Resources Association, 42(3), 593-601.

43. Malta G.N. 1172 of 2010 Environment Protection Act (Cap. 435) - Amendment to G.N. 1061 of 2005 Removal of officers from the list of officers authorized to act as Environmental Inspectors. 26 Nov 2010

44. McNeil L.S., Almasri M.N., and Mizyed N.A. (2009) Sustainable approach for reusing treated wastewater in agricultural irrigation in the West Bank - Palestine, Desalination, 248, 315-321.

45. MDG, Millenium Development Goal Water Indicators of the United Nations (2010) Databases. Proportion of total water resources used, percentage. http://unstats.un.org/

46. Mogheir Y., Abu Hujair T., Zomlot Z., Ahmed A. and Fatta D. (2005) Treated Wastewater Reuse in Palestine, International conference Water Value and Rights, Ramallah-Al-Bireh, Palestine May 2005

47. Morocco Ministry of Energy, Mining, Water and Environment (MEMEE) Guide of localized irrigation by sector

http://www.agriculture.gov.ma/sites/default/files/Guide_irrigation_localise_de_lagriculteur.pdf (in Arabic and French)

48. Papaiacovou I. (2001) Case study - wastewater reuse in Limassol as an alternative water source, Desalination, 138, 55-59.

49. Pedrero F., Kalavrouziotis I.K., Alarcon J., Koukoulakis P. and Asano T. (2009) Use of treated municipal wastewater in irrigated agriculture- Review of the practices in Spain and Greece, Agricultural Water Management, 97(9), 1233-1241. 
50. Salgot M., Pascual A. (1996) Existing guidelines and regulations in Spain on wastewater reclamation and reuse, Water Science and Tecnology, 34(11), 261-267.

51. Saqer S. (2005) A regional overview of wastewater management and reuse in the Eastern Mediterranean region (Available at: $\mathrm{http}: / /$ sarvab.com/Portals/7/Cod\%20194.pdf)

52. Special Secretariat for Water (SWW), (2009), Implementation of Degree 91/271/EC in Greece

53. UN WPP United Nations (2006) World Population Prospects: The 2006 Revision-Highlights; Volume III Analytical Report United Nations Population Division, Department of Economic and Social Affairs, 2006, www.un.org/esa/population/unpop.htm. (date accessed October 26, 2009)

54. U.S. Environmental Protection Agency (2004) Guidelines for Water Reuse. EPA/625/R-92/004, U.S. Environmental Protection Agency, Washington D.C. Chapter 8

55. WHO World Health Organization (2006) A compendium of standards for wastewater reuse in the Eastern Mediterranean Region, Document WHO-EM/CEH/142/E. 